\title{
Estimation of Salt Tolerance Degree in some Selected Wheat Genotypes by Using Detection of Salt Tolerant Gene (TaSTK) and its Expression Under Salinity Conditions
}

\section{H. Al-Mashhadani Ibrahim}

Biotechnology Research Center, Al-Nahrain University, Jadriah, Baghdad, Iraq

Email address:

hassanir11955@yahoo.com

\section{To cite this article:}

I. H. Al-Mashhadani Ibrahim. Estimation of Salt Tolerance Degree in some Selected Wheat Genotypes by Using Detection of Salt Tolerant Gene (TaSTK) and it Expression Under Salinity Condition. International Journal of Applied Agricultural Sciences.

Vol. 1, No. 2, 2015, pp. 31-35. doi: 10.11648/j.ijaas.20150102.13

\begin{abstract}
Molecular studies were carried out to detect salt tolerance gene (TaSTK) and estimate their expression in two selected cultivars (Dijilla and Furat) and one genotype (N3) of wheat under salinity condition $(0,15,25 \mathrm{ds} / \mathrm{m})$ as compared with salt sensitive cultivar (Tamooze-2). These cultivars and genotype were selected through plant breeding programs. The cDNA and gene amplification method used for this detection. Real-time PCR sybergreen method used to estimate the CT values and gene expression. The gene band length is $150 \mathrm{bp}$ which appeared only in the selected materials (salt tolerance), while this gene absent in the salt sensitive culture (Tamooze-2). Amount and expression of TaSTK gene to be enhanced under salt conditions, and the degree of salt related enhancement was greatly only in salt-tolerant materials. Excess expression and amount of the TaSTK gene were at high salinity levels. At all salinity levels also the results showed that the amount and expression of this gene were proximately similar in all selected materials by contrast, there were no amount and expression of this gene in sensitive culture (local cultivar).
\end{abstract}

Keywords: Wheat, Genotypes, Salinity, Salt Tolerance, TaSTK, Real-Time PCR

\section{Introduction}

Bread wheat is the most widely grown food crop in the world. In last few years, reduction in wheat production has occurred in major irrigated areas where wheat is an important crop (Curtis, et al. 2002). The environmental stresses cause plants limited growth or low production such as salt, drought, low temperature and high temperature. Salinity is one of the major stresses in aride and semi aride areas can reduce the growth and production of the field crops (Shannon, 1998).There is a need for new genotypes or cultivars with high salt tolerance through plant breeding programs; this requires new genetic sources of this character and more efficient techniques for identifying salt tolerance germaplasm (Al-Mishhadani, 2012). Induced new salt tolerant genotypes or cultivars of crop species are an attractive possibility for exploitation salt affected soils and for overcoming the salinity problems (Epstein, et al. 1980). The development of the technology and biotechnology technique is great achievement obtained providing a possibility to develop salt tolerant varieties effectively, so overcome this problem. Salt tolerance in plant depend on physiological mechanisms conferring this character which expressed by salt tolerant genes (Al-Mishhsdani, et al. 2014). Plants have evolved several mechanisms to acclimatize with salinity (Munns and Tester, 2008). The mechanisms of salinity tolerance becomes even more complicated when the response of a plant varies with the concentration of saline medium and the environmental conditions in which the plant is grown (Ashraf and Harris, 2004). During the last decade, a number of saltresponsive genes have been isolated and characterized (Sairam and Tyagi, 2004). New visions were appeared to try determining genes that play crucial role in plant tolerance to salinity (Tester and Roy, 2009).

One of these genes that involved in salt tolerance in wheat is TaSTG that induced expression under salt stress (Wang, et al. 2012) and the gene TaGSK1 that involved in ions uptake in wheat (Chen, et al. 2003).Geet al. (2012) identified a (Triticum aestivum)serine/threonine protein kinase gene (TaSTK) for salt tolerance. Serine/threonine protein kinases is a large protein family plays an important role in plants' stress signaling and responses such as high salt, drought, cold, etc. (Chenk, et al. 1999; Ferreira, et al. 1991; Stone and Walker, 
1995).

The present work aims to detect the salt tolerant gene (TaSTK) in some wheat genotypes selected for salt tolerance through plant breeding programs. Also to estimate the expression of this gene under salinity conditions to determine the salt tolerance degree in these selected materials.

\section{Material and Methods}

\subsection{Wheat Genotypes Selected}

Three selected wheat genotypes for salt tolerance and one local cultivar (check cultivar) were used in this study to detect the salt tolerant gene $(\mathrm{TaSTK})$ and its expression in these genotypes and local cultivar under salinity conditions. Seeds of selected genotypes of wheat (Dijilla, Furat and N3) and locale cultivar (Tamooze2) were planted in prepared soil salinity levels $(0,15$ and $25 \mathrm{ds} / \mathrm{m})$ with 5 seeds for each genotype and put under plastic house in Biotechnology Research Center /Al- Nahrain University in Baghdad, Iraq and irrigated with $100 \mathrm{ml}$ of normal water. Leaves samples were taken after 45 days from the sowing date for RNA extraction.

\subsection{RNA Isolation and CDNA Synthesis}

Table (1). Primers used for amplification of TaSTK and actin cDNA sequences.

\begin{tabular}{lllll}
\hline Gene & Primer & Sequence5'-3' & Genbank accession number & Reference \\
\hline \multirow{2}{*}{ TaSTK } & Forward & GTGCTGCTAAAGGGCTGGAA & \multirow{2}{*}{ AY956328 } & Primer Express 3.0 software \\
& Reverse & TGTCACCAACAGGACCCAATT & & \\
\multirow{2}{*}{ Actin } & Forward & TGGCACCCGAGGAGCACCCTG & AF326781.1 & (Guang et al., 2011) \\
& Reverse & GCGACGTACATGGCAGGAACA & & \\
\hline
\end{tabular}

\subsection{Gene Expression Analysis by SYBR Green Real-Time RT-PCR}

The expression TaSTK gene was examined bySYBR realtime RT-PCR using Exicycler real time PCR (Bioneer, Korea). One step RT-PCR was performed using premix RTPCR qPCR kit(Bioneer, Korea), following the manufacturers protocol. The thermal cycling profile consisted of initialdenaturation at $95^{\circ} \mathrm{C}$ for $5 \mathrm{~min}$ and 40 cycles at $95^{\circ} \mathrm{C}$ for $1 \mathrm{~min}, 58^{\circ} \mathrm{C}$ for $45 \mathrm{~s}$ and $72^{\circ} \mathrm{C}$ for $1 \mathrm{~min}$, followed with melting curve analysis at $60-95^{\circ} \mathrm{C}$. To confirm amplification specificity, the amplified fragments we reanalyzed by $1.5 \%$ agarose gel electrophoresis containing ethidiumbromide. Quantitation of relative expression was determined by the $2^{-(\Delta \Delta C T)}$ method (Livak and Schmittgen, 2001).Each sample was run in triplicate. For estimation of standard curve, online software was used to convert DNA concentration to log copy number

(http://www.uri.edu/research/gsc/resources/cndna.html).

\subsection{Statistical Analysis}

The values of the investigated parameters were given in terms of mean \pm standard error, and differences between means were assessed by analysis of variance (ANOVA) using SAS computer program version 7.5. Differences in results
Total RNA were isolated using Geneaidtotal RNA purification mini kit (Taiwan) according to the manufacturer's instructions. Isolated RNA was treated withRNase-free DNase set kit (Biobasic, Canada) for $20 \mathrm{~min}$ at $37^{\circ} \mathrm{C}$, DNaseI was inactivated at $65^{\circ} \mathrm{C}$ for $10 \mathrm{~min}$. The integrity of the RNA was verified after separation by electrophoresis on a $1.5 \%$ agarose gel containing $0.5 \%(\mathrm{v} / \mathrm{v})$ ethidium bromide. First-strand cDNA was synthesized from $500 \mathrm{ng}$ of total RNA using Reverse Transcription system (Bioneer, Korea) with an oligo- $\mathrm{dT}_{15}$ primer. The reaction solution was used as templates for reverse transcriptase polymerase chain reaction (RT-PCR).

\subsection{TaSTK Gene Amplification}

TaSTK (target gene) and wheat housekeeping B-actin (reference gene) cDNA were amplified using specific primers in table (1) which designed by Primer Express 3.0 software Center for Biotechnology Information (NCBI). Polymerase chain reaction was initiated with hot start method using the cDNA template on Labnet Thermo cycler(USA). The PCR reaction was carried out at $95^{\circ} \mathrm{C}$ for 5 min and 40 cycles at $95^{\circ} \mathrm{C}$ for $1 \mathrm{~min}, 58^{\circ} \mathrm{C}$ for $45 \mathrm{~s}$ and $72^{\circ} \mathrm{C}$ for $1 \mathrm{~min}$. according to the sequence of the gene TaSTK in National

were considered significant at probability value equal or less than 0.001(SAS, 2004).

\section{Results}

\subsection{PCR Reaction-DNA}

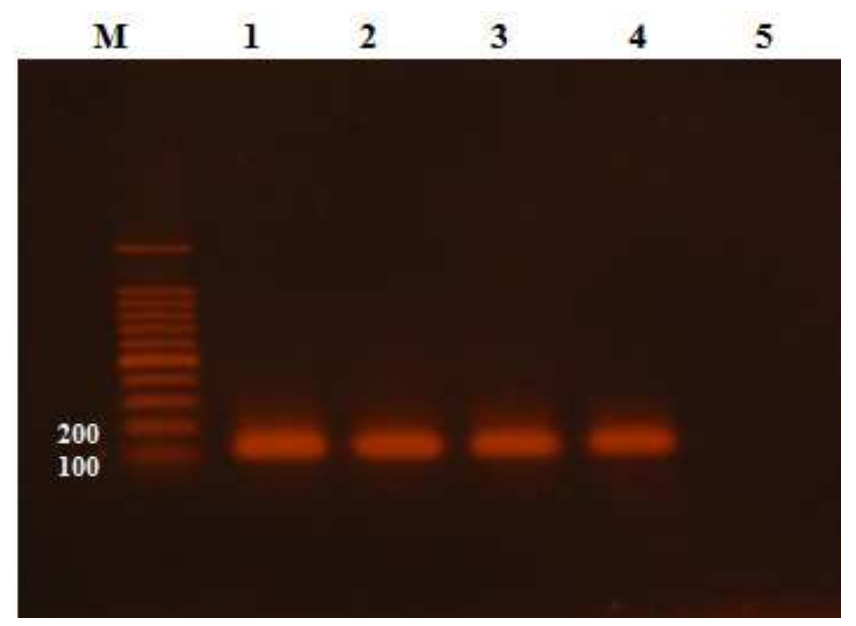

Figure (1). Ethidium bromide stained agarose electrophoresis (1.5\%) of PCR Product (TaSTK gene)for wheat cultivars. M: Marker (100bp), 1: Furat cultivar, 2: Dijila cultivar, 3: N3 genotype, 4: Tamooze 2 cultivar, 5: Negative control. 
The results of the amplification were shown in fig. (1), it was revealed that there were no differences between the selected cultivars and genotype as compared with local cultivar (Tamooze-2) in their banding patterns, this reflect that all cultivars and genotype had the same band with $150 \mathrm{bp}$, while this band was absent in negative control.

\subsection{Qualitative PCR Reaction-CDNA}

The amplification of the TaSTK salt tolerant gene was done by conventional PCR reaction after optimizing of the primers After staining with ethidium bromide and visualized under UV light. The results in fig. 2 showed that the size of TaSTK gene amplification band was $150 \mathrm{bp}$ according to the DNA ladder. These results indicated that salt tolerant gene (TaSTK) was appeared only in the selected genotype and cultivars at salinity condition, while this gene band was absent in both local cultivar (Tamooze-2) and the negative control at the same conditions. From the above results we can confirmed that the salt tolerant gene ( $T a S T K)$ was found in the cultivars and genotype which selected for salt tolerance through plant breeding programs, while this gene was absent in the sensitive cultivar (Tamooze-2). Also the results indicated that the gene band that appeared only in the selected cultivars and genotypes has the same size (150bp).

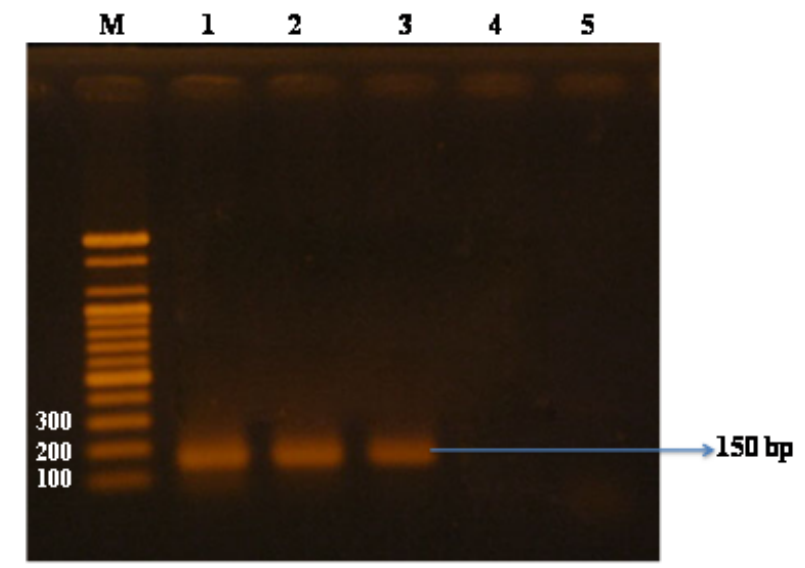

Figure (2). Ethidium bromide stained agarose electrophoresis (1.5\%) of PCR Product (B-actin gene)for wheat cultivars. M: Marker (100bp), 1: Furate cultivar, 2: Dijila cultivar, 3: N3 genotype, 4: Tamooze 2 cultivar, 5: Negative control.

\subsection{Quantitative Real-Time PCR}

Real-time PCR can provide clear information about the determination of the amount of a certain gene in the sample, which correlated with the threshold cycle $\left(\mathrm{C}_{\mathrm{T}}\right)$ (Livak and Schmittgen, 2001). Estimation of $\mathrm{C}_{\mathrm{T}}$ values depended on the results which summarized in fig. 3 . The average of $C_{T}$ values at each salinity level was summarized in table 2 . The values of $\mathrm{C}_{\mathrm{T}}$ were negative correlation with the amount of the salt tolerant gene $($ TaSTK $)$. The results of $\left(\mathrm{C}_{\mathrm{T}}\right)$ values showed that these values of each selected cultivars and genotype (Furat, Dijilla and N3) decreased with increasing salinity levels, and these prove that the amount of the TaSTK gene increased with increasing salinity levels. Whilst, the result of $\left(\mathrm{C}_{\mathrm{T}}\right)$ values also revealed that these values of the local cultivar (Tamooze-2) was zero and this mean that the local cultivar does not have any amount from the salt tolerant gene under salinity condition.

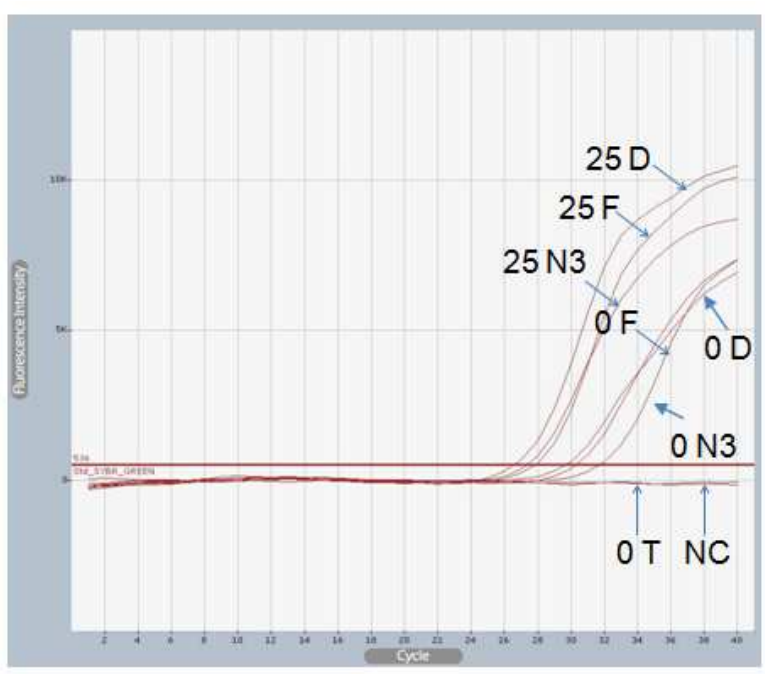

Figure (3). listed values of TaSTK gene for each concentration of saline and each sample of wheat genotypes studied.

Table (2). Average of $C_{T}$ value of STK gene SYBR green real time PCR amplification.

\begin{tabular}{lll}
\hline Genotypes & Salt concentration ds/m & $\begin{array}{l}\mathbf{C}_{\mathbf{T}} \text { value of STK gene } \\
\text { Average }\end{array}$ \\
\hline \multirow{3}{*}{ Furat } & 0 & $32.17 \pm 0.11$ \\
& 15 & $26.53 \pm 0.56$ \\
& 25 & $20.21 \pm 0.44$ \\
Dijila & 0 & $32.18 \pm 0.11$ \\
& 15 & $25.91 \pm 0.45$ \\
& 25 & $20.02 \pm 0.35$ \\
N3 & 0 & $31.62 \pm 0.10$ \\
& 15 & $26.01 \pm 0.55$ \\
\multirow{3}{*}{ Tamooze 2 } & 0 & $19.92 \pm 0.33$ \\
& 15 & ---- \\
\hline
\end{tabular}

Also the results indicated that the amounts of TaSTK gene were similar in all selected cultivars and genotype, but differed significantly with increasing salinity levels.

In order to study gene expression, the efficiency of QPCR was determined by using several serial decimal dilutions of eluted PCR band. The logarithm of gene copy numbers were estimated according to DNA concentration using the online software DNA copy number (fig. 4). The amplification of the salt tolerant gene (TaSTK) was done by SYBR green realtime PCR to estimate the expression of this gene in the selected wheat cultivars and genotype (Furat, Dijilla and N3) as compared with the local cultivar (Tamooze-2) (Table 3 ). The results of the analysis of the real-time PCR showed that there are expressions of TaSTK gene under all salinity conditions, and there are differences in their expressions among the salt levels. However, the gene expression 
increased with increasing salt levels (fig. 3). The selected wheat cultivars and genotype gave gene expression at all salinity levels, while the local cultivar (Tamooze-2) did not show any gene expression under the same salinity conditions (Fig. 3 and table 4 ).The expression of gene TaSTK of these selected materials was increased with increasing salinity levels, and the highest expressions were at the highest salinity level $(25 \mathrm{~d} / \mathrm{m})$ (table 4,fig. 3). By contrast, the lowest expressions were at the normal condition $(0 \mathrm{ds} / \mathrm{m})$.

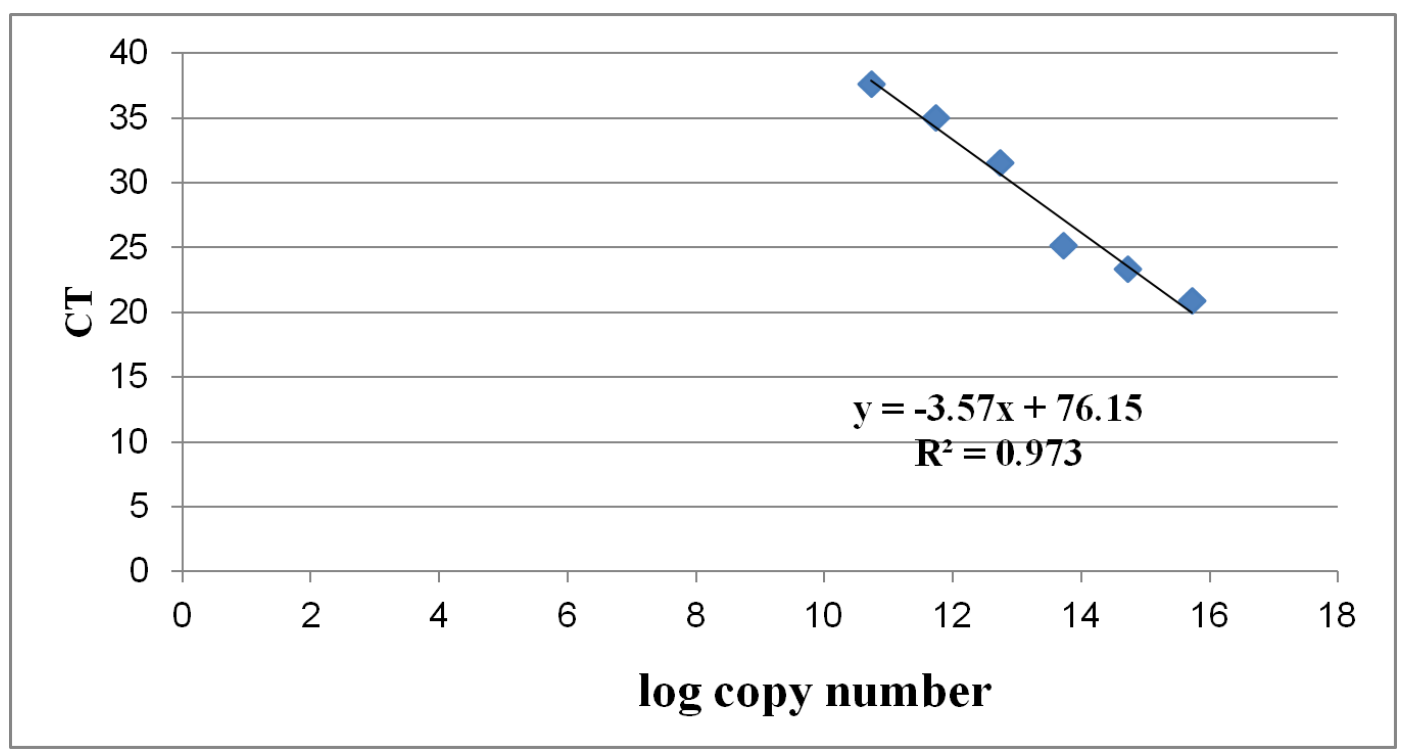

Figure (4). Standard curve shows slope and $R^{2}$ values to determine the efficiency of QPCR reaction for STK gene amplification.

Table (3). Values of STK gene expression.

\begin{tabular}{llll}
\hline Genotypes & $\begin{array}{l}\text { Salt } \\
\text { concentrati } \\
\text { on ds/m }\end{array}$ & $\begin{array}{l}\text { CT( STK) - CT } \\
\text { (ACTIN) }\end{array}$ & $\begin{array}{l}\text { Gene } \\
\text { expression=E } \\
\text { (STK) }- \text { Ct (ACTIN) }\end{array}$ \\
\hline \multirow{3}{*}{ Furat } & 0 & $8.52 \pm 0.56$ & $0.43 \pm 0.67$ \\
& 15 & $3.1 \pm 0.11$ & $0.73 \pm 0.34$ \\
& 25 & $-3.15 \pm 0.00$ & $1.36 \pm 0.12$ \\
Dijila & 0 & $8.62 \pm 0.56$ & $0.42 \pm 0.66$ \\
& 15 & $2.42 \pm 0.13$ & $0.78 \pm 0.49$ \\
& 25 & $-3.93 \pm 0.00$ & $1.47 \pm 0.17$ \\
N3 & 0 & $8.48 \pm 0.55$ & $0.43 \pm 0.45$ \\
& 15 & $2.15 \pm 0.16$ & $0.80 \pm 0.17$ \\
& 25 & $-3.45 \pm 0.00$ & $1.40 \pm 0.90$ \\
Tamooze 2 & 0 & ----- & ----- \\
& 15 & ----- & ---- \\
\hline
\end{tabular}

\section{Discussion}

The results in fig. 1 indicated that there were no differences between the selected materials (salt tolerant) and local cultivar (salt sensitive) in their band pattern under salinity condition at the DNA level, while the gene band appeared in the selected cultivarsand genotype and absent in the local cultivar under the same salt conditions (fig.2), but at the cDNA level.This may be due to the absence of the TaSTK gene or their expression in the local cultivar under salinity conditions, also this absence due to either to the banding of the $\mathrm{CH} 3$ group in coding region (methylation) (Hohn et al., 1996)or to the protein inhibitor (Bateman and James, 2011).Therefore, these results reflect that there is a high correlation between TaSTK gene and salt tolerance of the selected cultivars and genotype under salinity condition, while the salt sensitive of the local cultivar was more correlated with the absence of this gene (fig.2). In the fact, these selected cultivars and genotype were identified as a salt tolerant materials while the local cultivar was identified as a sensitive culture (Al-mishhadani, 2012; Al-mishhadani et.al 2014 and Al-mishhadani, 2015) . on the other hand, Ge et. al. (2007) reported that TaSTK gene was cloned from a salt resistant wheat line RH8706-49 based on differential expression studies of this salt - resistant line versus a cDNA $-\mathrm{AFLP}, \mathrm{RACE}$ and gene located in the 2BL and 2DL chromosome and has two copies. Expression of the TaSTK gene and the degree of salt related enhancement was greater in salt - resistant material RH8706-49 than that in the saltsensitive material H8706-34.

Excess expression of the gene (TaSTK) was demonstrated to increase the growth of the roots in salt containing medium and improve the tolerance of the plant against salt stress (Ge et. al. 2007). Similarly the salt tolerant gene (TaSTK) was detected only in the salt tolerant cultivars and genotype which induced through plant breeding programs as a salt tolerant genotypes and this gene gave high expression under high salinity condition. Previously, these selected cultivars and genotype gave high roots growth under high salinity conditions as compare with the roots growth of the local cultivar(Al-Mishhadani, 2012; Al-Mishhadani et.al 2014, 2015). Other salt tolerant gene (TaGSK1) was detected in these selected cultivars and genotype (Ismail, 2013), and also she reported that this gene gave high expression under high salinity conditions.

The results of this research revealed that the amount of TaSTK gene of all selected material increased with increasing salinity levels. Previously, research indicated that the salt 
tolerant degree in any plant depend on the kind and amount of salt tolerant genes which segregated through cycles of screening and selected (Munns, 2005). Clearly these genes control the salt mechanisms, which determine salt tolerance degree in plants. The superiority of selected materials in salt tolerance of local cultivar due to the presence of salt tolerant gene with gave high expressions and gene amounts under high salinity levels. In fact, the selected genotype and cultivars used in this research were derived from seedling which still alive after exposure to the $30 \mathrm{ds} / \mathrm{m}$ drainage water for six cycles of screening and selection at germination and early seedling stage. Therefore, the salt tolerance character is transferred through generations and genetic improvement or advance for salt tolerance is realized through these cycles, because the salt tolerance is clearly in herited (Azhar and McNeilly, 1989; Al-Mishhadani, et.al 2003).

Generally, these results concluded that the salt tolerant gene (TaSTK) found only in the selected cultivars and genotype, and this gene gave high expression and amount under high salinity levels $(25 \mathrm{ds} / \mathrm{m})$.

\section{References}

[1] AL-Mishhadani, I. H.; Al-shamma, A. M. and Attiya, H. J. (2003). Some genetic studies of salt tolerance in yield and its component of some selected genotypes of wheat. J. of Iraq Agri. Sci. 34(2):111-118.

[2] Al-Mishhadani, I. I. H. (2012). Breeding and selection of some Lines of Bread Wheat for salt tolerance. Journal of Agricultural Science and Techbology B. 2(8):934-939.

[3] Al-Mishhadani, I. I. H.; Abdula, K. H.; Isamil, E. N.; Thahre, Y. D. and Weab, I. A. (2014). Estimation of new wheat genotypes for salt tolerance which induced through plant breeding programs. Journal of Agricultural Science and Techbology B. 4(2):150-156.

[4] Al-Mishhadani, I. I. H.; Zakariya, B. F.; Ismail, E. N. and Wisam, M. D. (2015). Detection for salt tolerance character in two selected genotypes of wheat. International Journal of Biology. 7(1): 54- 60.

[5] Ashraf, M. and Harris, P. J. C. (2004). Potential biochemical indicators of salinity tolerance in plants. Plant Science. 166, $3-16$.

[6] Azhar, M. and MeNeilly, T. (1989). Heritability estimates of variation for Nacl tolerance in Sorghum biocolor L., J. Agronomy and Crop Sci.43: 69-72.

[7] Bateman, K. S. and James, M. N. (2011). Plant protein proteinase inhibitors: structure and mechanism of inhibition.Curr Protein Pept Sci. 12(5): 340-7.
[8] Chen, G. P.; Ma, W. S.; Huang, Z. J.; Xu, T.; Xue, Y. B. and Shen, Y. Z. (2003). Isolation and characterization of TaGSK1 involved in wheat salt tolerance. Plant Sci. 165, 1369-1375.

[9] Chenk, P. W. and Snaar-Jagalska, B. E. (1999). Signal perception and transduction: the role of protein kinases, Biochim. Biophys. 49, 1-24.

[10] Curtis, B.C.; Rajaram, S. and Gómez Macpherson, H. (2002). Bread Wheat. Improvement and production. FAO Plant Production and Protection Series No. 30.

[11] Epstein, E.; Norlyn, J. D.; Rush, D. W.; Kingsbury, R.W.; Kelley, D. B.; Cunningham, G. A., and Wrona, A. F. (1980). Saline culture of crop: A genetic approach. Science. 210:399404.

[12] Ferreira, P. G. (1991). The Arabidopsis functional homolog of the P34cdc2 protein kinase, Plant Cell 3, 531-540.

[13] Ge, R-C, Chen, G-P, Zhao, B-C, Shen, Y-Z and Huang, Z-J (2012). Cloning and functional characterization of a wheat serine/threonine kinase gene (TaSTK) related to salt-resistance. Plant Science 173, 55-60.

[14] Hohn, T.; Corsten, S.; Rieke, S.; Muller, M. and Rothnie, H (1996). Methylation of coding region alone inhibits gene expression in plant protoplasts. Proc. Natl. Acad. Sci. USA; Vol. 93: pp. 8334-8339.

[15] Ismail, E. N. (2013). Determination of gene expression of salt tolerant gene TaGSK1 in wheat cultivars Triticum aestivum L. Baghdad University.

[16] Livak, K. J. and Schmittgen, T. D. (2001). Analysis of Relative Gene Expression Data Using Real-Time Quantitative PCR and the $2^{-\Delta \Delta} C_{\mathrm{T}}$ Method. Methods. 25, 402-408.

[17] Munns, R. (2005). Genes and salt tolerance: bringing them together. New Phytol 167: 645-663.

[18] Munns, R. and Tester, M. (2008). Mechanisms of salinity tolerance. Annual Review of Plant Biology. 59, 651-681.

[19] Sairam, R. K. and Tyagi, A. (2004). Physiological and molecular biology of salinity stress tolerance in plants. Curr. Sci. 86(3): 407-421.

[20] Shannon, M. C. (1998). Adaptation of plants to salinity. Adv. Agron. 60, 75-119.

[21] Stone, J. M. and Walker, J. C. (1995). Plant protein kinase families and signal transduction, Plant Physiol. 108, 451-457.

[22] Tester, K. M. R. and Roy, S. J.(2009). Quantifying the three main components of salinity tolerance in cereals. Plant, Cell and Environment. 32, 237-249.

[23] Wang, W.; Vinocur, B. and Altman, A. (2003). Plant responses to drought, salinity and extreme temperatures: towards genetic engineering for stress tolerance. Planta 218:1-14. 